\title{
Daun Kelor Memperbaiki Histopatologi Hati Tikus Putih Yang Mengalami Diabetes Melitus
}

\author{
(MORINGA LEAVES IMPROVE HYSTOPATOLOGY WHITE RATS HEPAR \\ EXPERIENCED DIABETIC)
}

\author{
Ida Ayu Adhistania Pidada ${ }^{1}$, Ni Luh Eka Setiasih ${ }^{2}$, Ida Bagus Oka Winaya ${ }^{3}$ \\ ${ }^{1}$ Mahasiswa Program Profesi Dokter Hewan Fakultas Kedokteran Hewan \\ ${ }^{2}$ Laboratorium Histologi, Fakultas Kedokteran Hewan, Universitas Udayana \\ ${ }^{3}$ Laboratorium Patologi, Fakultas Kedokteran Hewan, Universitas Udayana \\ J1. PB. Sudirman, Denpasar-Bali. Email: adhiztania@gmail.com
}

\begin{abstract}
ABSTRAK
Penelitian ini bertujuan untuk mengetahui histopatologi hati pada tikus putih diabetes melitus eksperimental setelah pemberian ekstrak etanol daun kelor (Moringa oleifera). Sebanyak 24 ekor tikus putih jantan diinduksi Streptozotocin dosis tunggal sebesar $45 \mathrm{mg} / \mathrm{Kg}$ BB secara intraperitoneal untuk menyebabkan diabetes melitus. Setelah dinyatakan diabetes, tikus dibagi menjadi 6 kelompok terdiri 1 kelompok kontrol dan 5 kelompok perlakuan yang diberi ekstrak etanol daun kelor, dengan dosis $100 \mathrm{mg} / \mathrm{Kg} \mathrm{BB}, 200 \mathrm{mg} / \mathrm{Kg} \mathrm{BB}, 300 \mathrm{mg} / \mathrm{Kg} \mathrm{BB}, 400 \mathrm{mg} / \mathrm{Kg} \mathrm{BB}, 500 \mathrm{mg} / \mathrm{Kg} \mathrm{BB}$, selama 5 minggu. Tikus lalu dikorbankan dan diambil organ hati nya untuk dibuat histopatologi dengan pewarnaan Hematoxylin Eosin (HE). Preparat histopatologi diperiksa dibawah mikroskop pada lima lapang pandang dengan pembesaran 400x. Data diproses kemudian dianalisis secara statistik dengan uji Non Parametrik Kruskal Wallis. Hasil penelitian menunjukkan organ hati yang menderita diabetes mellitus mengalami perbaikan gambaran histopatologi setelah pemberian ekstrak etanol daun kelor dengan dosis $400 \mathrm{mg} / \mathrm{Kg} \mathrm{BB}$.
\end{abstract}

Kata kunci: diabetes mellitus; ekstrak daun kelor; histopatologi hati.

\begin{abstract}
This study aims to determine the improvement of hepar histopathologic on experimental diabetic rats after given moringa oleifera leaves ethanolic extract. Twenty-four male white rats induced by a single dose Streptozotocin of $45 \mathrm{mg} / \mathrm{kg}$ intraperitoneally to cause diabetes mellitus. After exposure to diabetes, the rats were divided into 6 groups consist of 1 a control group and 5 treatment groups were given moringa oleifera leaves ethanol extracts, dose of 100, 200,300,400, and 500 $\mathrm{mg} / \mathrm{kg}$, for 5 weeks. The rats then sacrificed and the hepar were collected for the histopathology preparations with Hematoxylin-Eosin staining (HE). Each histopathology preparation was examined under a microscope in five visual fields at 400x magnification. The data were processed and then analyzed statistically by Non parametrics Kruskal Wallis. The results showed that the hepar improved due to damage diabetes mellitus after given Moringa oleifera leaves ethanolic extract with a dose of $400 \mathrm{mg} / \mathrm{kg}$.
\end{abstract}

Keywords: diabetes mellitus; Moringa oleifera; hepar histopathology

PENDAHULUAN

Diabetes melitus (DM) merupakan salah satu jenis penyakit metabolik yang selalu mengalami peningkatan setiap tahun di negara-negara seluruh dunia. Berdasarkan perolehan data International Diabetes Federation (IDF) tingkat prevalensi global penderita DM pada tahun 2014 sebesar 8,3\% dari populasi penduduk dunia. International Diabetes Federation (IDF) memperkirakan pada tahun 2035 jumlah insiden DM akan mengalami peningkatan menjadi 55\% (592 juta) di antara usia penderita DM 20-79 tahun (IDF, 2014). Kejadian penyakit ini sangat bervariasi tergantung beberapa faktor diantaranya faktor stres, gizi (hiperglikemia), radikal bebas, genetik, infeksi, dan faktor lainnya yang berakibat pada kerusakan sel-sel beta pankreas sehingga tidak mampu memproduksi insulin (Stumvoll et al., 2005). 
Kasus diabetes biasanya ditandai adanya gangguan sekresi insulin ataupun gangguan kerja insulin (resistensi insulin) pada organ target terutama hati dan otot. Organ hati merupakan organ dalam tubuh terbesar dan merupakan pusat metabolisme yang paling kompleks di dalam tubuh (Corwin, 2001). Glukagon dan insulin memegang peran penting dalam metabolisme karbohidrat, protein, dan lemak. Bahkan keseimbangan kadar gula darah dipengaruhi dua hormon ini. Selain organ tempat metabolisme, hati juga sebagai tempat penyimpanan nutrisi yang diserap dari saluran pencernaan untuk selanjutnya dipakai oleh bagian tubuh lainnya (Dalimartha, 2001).

Pada penelitian hewan coba diabetes melitus, bahan kimia toksik yang banyak dipakai dalam penelitian yaitu Streptozotocin (STZ). Streptozotocin digunakan menginduksi diabetes mellitus pada hewan coba karena kerjanya spesifik untuk kerusakan sel $\beta$ pankreas (Nugroho, 2006). Kerusakan pankreas akan menentukan tipe diabetes yaitu diabetes tipe I terjadi defisiensi insulin serta jumlah sel $\beta$ pankreas yang rusak $70-80 \%$ dan pada diabetes tipe II terjadi kurang pekanya reseptor insulin dan juga mengalami kerusakan sel $\beta$ 25-50\% (Cnop, 2005).

Salah satu jenis tanaman yang digunakan sebagai obat tradisional untuk menurunkan kadar glukosa darah adalah tanaman kelor (Moringa olifera) (Jaiswal et al., 2009). Daun kelor mengandung 46 antioksidan, dimana dapat menghambat atau menghancurkan rantai peroksida (Putri, 2016).

Hasil penelitian sebelumnya mengungkapkan bahwa pemberian ekstrak etanol daun kelor pada dosis $150 \mathrm{mg} / \mathrm{kg}$ $\mathrm{BB}$ dan $300 \mathrm{mg} / \mathrm{kg}$ BB dapat menurunkan kadar glukosa darah (Edoga et al., 2013, Aini et al., 2015). Oleh karena itu perlu dilakukan penelitian untuk mengetahui efek ekstrak etanol daun kelor untuk memperbaiki struktur pada organ hati secara histopatologi.

\section{METODE PENELITIAN}

\section{Materi Penelitian}

Penelitian menggunakan tikus putih (Rattus novergicus) jantan berumur 3-4 bulan dengan berat badan berkisar 200-250 gram sebanyak 24 ekor. Tikus diadaptasikan terlebih dahulu dengan lingkungan selama satu minggu. Bahan yang digunakan berupa daun kelor yang diekstraksi di Unit Layanan Laboratorium Fakultas Teknologi Pertanian Universitas Udayana.

\section{Pembuatan ekstrak daun kelor}

Daun kelor yang sudah bersih dikeringkan pada suhu ruangan. Setelah mencapai berat kering konstan lalu dihancurkan dengan menggunakan blender dan diayak sehingga diperoleh tepung daun kelor. Tepung tersebut kemudian dimaserasi menggunakan etanol 96\% selama 48 jam. Maserasi merupakan jenis ekstraksi secara dingin sehingga mencegah kerusakan kompenen kimia yang tidak tahan terhadap pemanasan (Syukur et al., 2011). Hasil maserasi etanol tersebut kemudian disaring dengan kertas saring sehingga di dapat maserat daun kelor. Maserat daun kelor kemudian dimasukkan ke dalam rotary vacuum evaporator pada suhu $45^{\circ} \mathrm{C}$ sampai seluruh pelarut menguap, selanjutnya ekstrak daun kelor disimpan dalam refrigerator dengan suhu $10^{\circ} \mathrm{C}$ (Dima et al., 2016).

\section{Perlakuan pada tikus putih}

Tikus putih jantan dengan berat 200 s/d 250 gram diadaptasikan dengan lingkungan selama satu minggu, kemudian diberikan STZ (Streptozotocin) dosis tunggal sebesar $45 \mathrm{mg} / \mathrm{KgBB}$ intraperitonial. Tiga hari setelah injeksi STZ, dilakukan pengukuran kadar glukosa darah. Bila kadar glukosa darah sebesar 400-500 mg/dl, tikus baru dinyatakan diabetes melitus. Tikus diabetes diambil dan di kelompokkan menjadi 6 kelompok, masing-masing kelompok terdiri dari 4 ekor tikus diabetes melitus eksperimental. Kelompok 1/K0 (diabetes kontrol, ekstrak daun kelor dosis $0 \mathrm{mg} / \mathrm{kg} \quad \mathrm{bb} / \mathrm{hari}$ ), 
kelompok 2/K1 (ekstrak daun kelor dosis $100 \mathrm{mg} / \mathrm{kg}$ bb/hari), kelompok 3/K3 (ekstrak daun kelor dosis $200 \mathrm{mg} / \mathrm{kg}$ bb/hari), kelompok 4/K4 (ekstrak daun kelor dosis $300 \mathrm{mg} / \mathrm{kg}$ bb/hari), kelompok $5 / \mathrm{K} 5$ (ekstrak daun kelor dosis $400 \mathrm{mg} / \mathrm{kg}$ bb/hari), dan kelompok 6/K5 (ekstrak daun kelor dosis $500 \mathrm{mg} / \mathrm{kg} \mathrm{bb} / \mathrm{hari}$ ). Pemberian ekstrak etanol daun kelor dilakukan peroral menggunakan sonde lambung selama lima minggu. Setelah lima minggu tikus putih atau hewan coba dikorbankan untuk diamati organ hatinya. Organ tersebut difiksasi dalam Neutral Buffered Formalin $10 \%$ untuk kemudian diproses menjadi preparat histopatologi.

\section{Pembuatan preparat histopatologi}

Perlakuan sesuai kelompoknya dilakuakan selama 5 minggu. Hari ke 36 semua tikus dikorbankan, kemudian diambil organ hati untuk selanjutnya dibuat preparat histopatologi. Pembuatan preparat histopatologi dibuat sesuai prosedur Kiernan (2001) dan pewarnaan dengan metode Harris hematoksilin-eosin (HE).

\section{Analisis data}

Data yang diperoleh dianalisis secara statistik dengan Uji Non Parametik Kruskal Wallis. Jika terdapat perbedaan yang bermakna $(\mathrm{P}<0,05)$ maka dilanjutkan dengan Uji Mann-Whitney. Prosedur analisis menggunakan program SPSS 17 (Sampurna dan Nindhia, 2008).

\section{HASIL DAN PEMBAHASAN}

\section{Hasil}

Gambaran histopatologi hati tikus putih, ditemukannya infiltrasi sel radang, degenerasi melemak, serta nekrosis. Perubahan struktur histologi hati dipengaruhi oleh jumlah dan jenis senyawa yang masuk ke dalam organ hati, termasuk pemberian ekstrak daun kelor pada tikus (Swarayana et al., 2012). Pada perlakuan kelompok K1, K2 kerusakan hati masih seperti yang dialami pada kelompok kontrol, sedangkan pada kelompok perlakuan K3 dan K4, degenerasi melemak dan nekrosis mulai tidak terlihat pada lima lapang padang. Sebaliknya pada kelompok perlakuan K5 kerusakan hati kembali mulai meningkat seperti pada kelompok K2 dan kontrol. Gambaran histopatologi pada hati tikus diabetes melitus pasca pemberian ekstrak daun kelor dapat dilihat pada Gambar 1.

\section{Pembahasan}

Hasil dari analisis statistik uji Kruskal-Wallis pada penelitian tikus diabetes melitus eksperimental yang diberikan ekstrak daun kelor menunjukkan adanya perbedaan yang signifikan $(\mathrm{P}<0,05)$. Hepatosit secara normal tersusun secara teratur membentuk lempenglempeng sel dan nukleus bulat serta sitoplasmanya yang cerah. Proses kerusakan sel hati dimulai dari proses degenerasi, perubahan ini bersifat revesibel karena dapat kembali normal. Organ hati memegang peranan penting sebagai penjaga (buffering) hiperglikemia postprandial dengan melibatkan mekanisme sintesis glikogen (Suarsana et al., 2010). Suarsana et al., (2010) pada keadaan diabetes melitus terjadi kegagalan kemampuan hati di dalam sintesis glikogen, dikarenakan pada tikus diabetes induksi streptozotocin, enzim glikogen sintase fosfatase dalam bentuk aktif menjadi defektif sehingga aktivitasnya berkurang. Hiperglikemia pada tikus yang diinduksi STZ sejalan dengan penelitian Adji (2008) yang menyebabkan kerusakan sel $\beta$ pankreas sehingga sel-sel mengalami degenerasi, nekrosis, dan resopsi sehingga mengurangi dan mencegah produksi insulin. Ini berkaitan dengan kerja STZ dan peroksidasi lipida, dimana produksi radikal bebas yang berlebihan atau kurangnya jumlah antioksidan, akan menyebabkan oksidasi sel lemak, protein, dan asam nukleat, menyebabkan fragmentasi atau cross-linking. Degenerasi melemak merupakan akumulasi lemak dalam sitoplasma sel. Penyebabnya antara lain adalah gangguan hepatosit akibat defisiensi makanan dan keracunan 
(toksik). Sedangkan nekrosis merupakan kematian sel/jaringan akibat proses
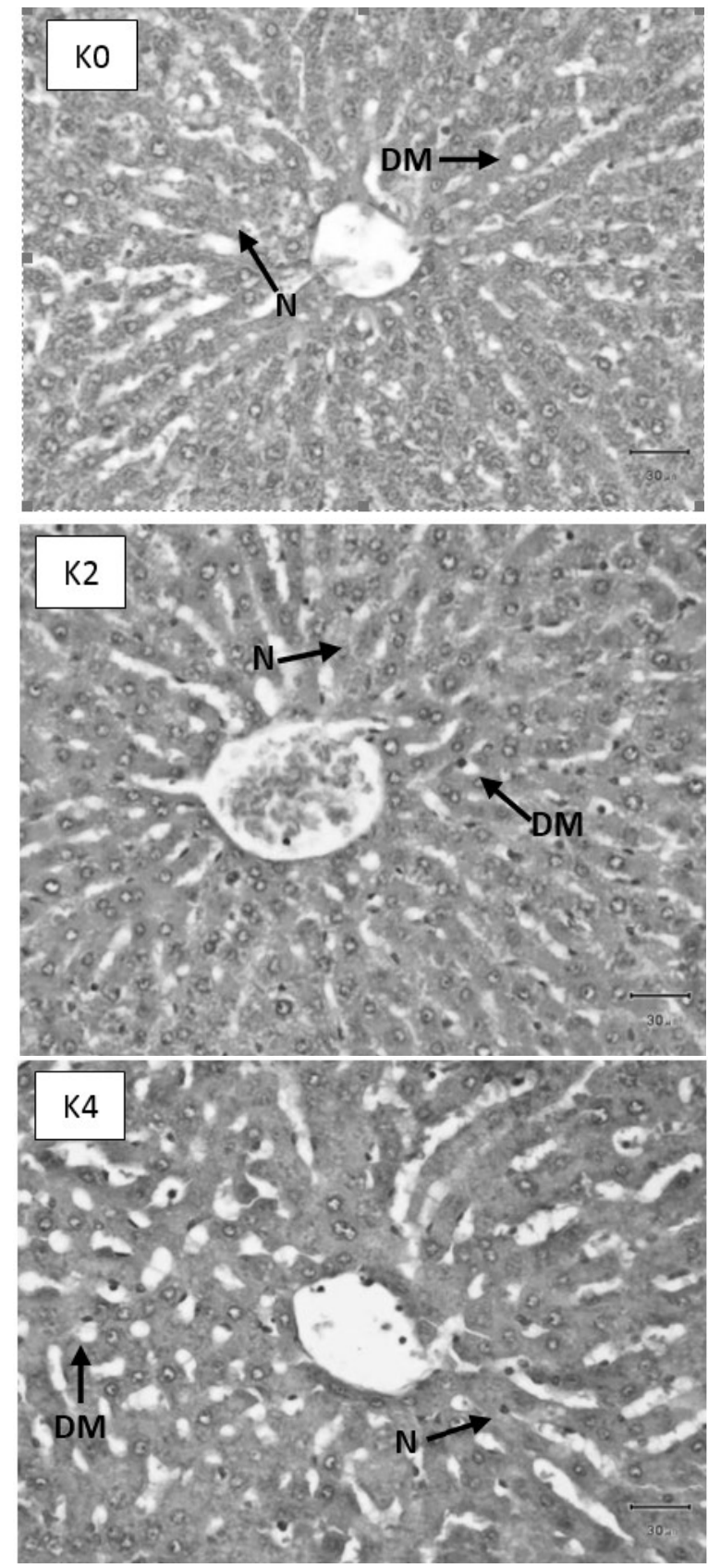

degenerasi yang ireversibel (Berata et al., 2014).
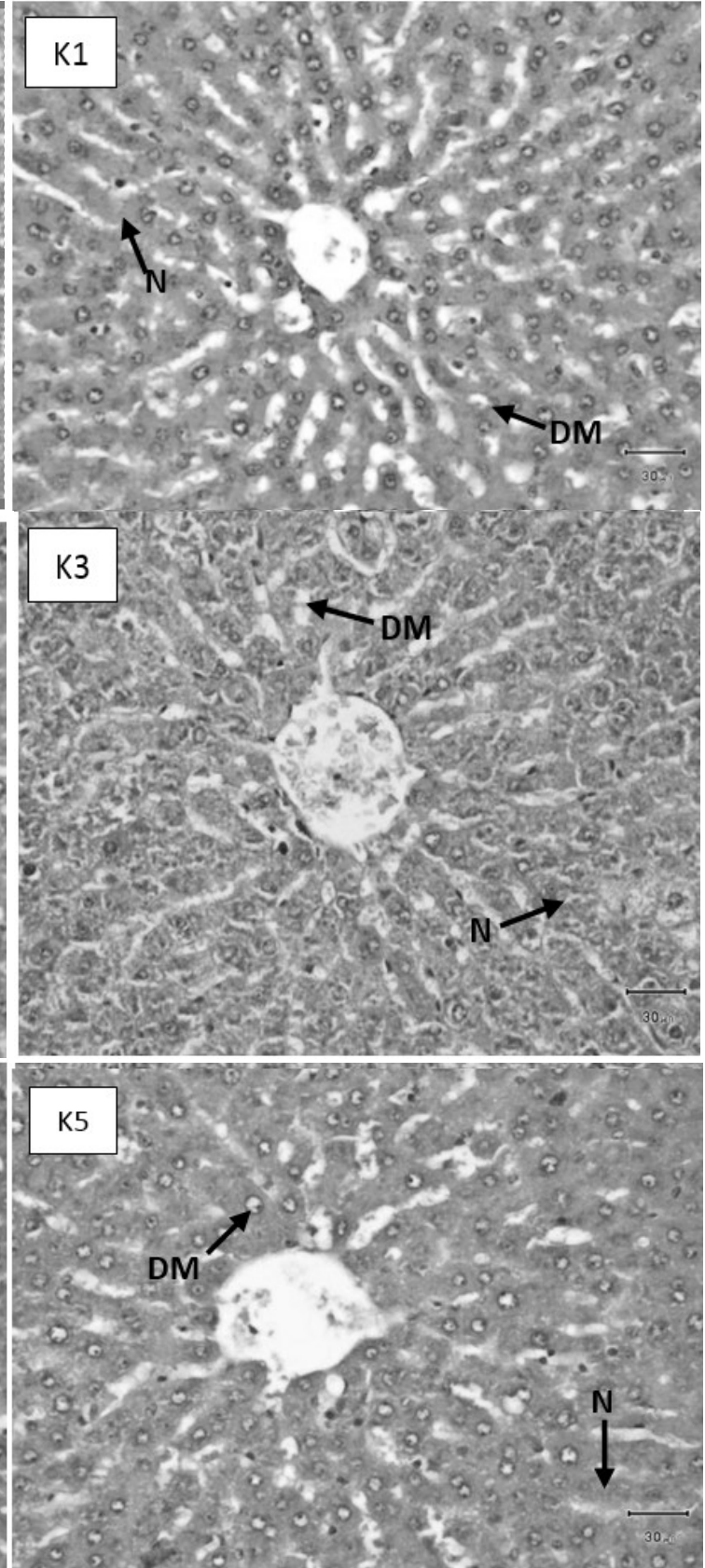

Gambar 1. Struktur Histopatologi Hati Diabetes Melitus Pada Tikus Putih Yang Diberikan Ekstrak Etanol Daun Kelor (HE, 400x).

Keterangan : $\mathrm{DM}=$ Degenerasi melemak, $\mathrm{N}=$ Nekrosis, $\mathrm{K} 0=$ Kontrol positif, $\mathrm{K} 1=$ Perlakuan tikus putih kelompok 1 pemberian ekstrak etanol daun kelor dosis $100 \mathrm{mg} / \mathrm{KgBB}$, $\mathrm{K} 2=$ Perlakuan tikus putih kelompok 1 pemberian ekstrak etanol daun kelor dosis 200mg/KgBB, K3 = Perlakuan tikus putih kelompok 1 pemberian ekstrak etanol daun kelor dosis $300 \mathrm{mg} / \mathrm{KgBB}, \mathrm{K} 4=$ Perlakuan tikus putih kelompok 1 pemberian ekstrak etanol daun kelor dosis $400 \mathrm{mg} / \mathrm{KgBB}, \mathrm{K} 5=$ Perlakuan tikus putih kelompok 1 pemberian ekstrak etanol daun kelor dosis $500 \mathrm{mg} / \mathrm{KgBB}$.

Hasil pengamatan histopatologi hati tikus diabetes melitus pada kelompok kontrol menunjukkan adanya degenerasi melemak dan nekrosis yang memiliki nilai modus rata-rata dua (multifokal) dan tiga (difusa). Pada kelompok perlakuan K1 dan 
K2 memiliki gambaran mikrokopis yang tidak jauh berbeda dari kelompok K0. Degenerasi terjadi akibat dari hiperglikemia dan hambatan produksi insulin yang dilihat secara mikroskopik yang sesuai dengan pendapat Mardiastuti (2002) tampak degenerasi melemak berupa droplet-droplet lemak pada lobulus hati di sekitar vena sentralis dan paling sering terlihat di bagian perilobuler. Kerusakan hati pada kelompok perlakuan K3 dan K4 degenerasi melemak dan nekrosis terhitung mulai berkurang, seperti yang ditampilkan pada gambar 2. Struktur sel hati kelompok perlakuan $\mathrm{K} 4$ terlihat sudah membaik mendekati struktur sel hati normal.

Tabel 1. Data Hasil Pemeriksaan Mikroskopis Perbaikan Histopatologi Hati

\begin{tabular}{ccc}
\hline $\begin{array}{l}\text { Perubahan } \\
\text { Histopatologi }\end{array}$ & Perlakuan & Rerata \\
\hline \multirow{4}{*}{ Degenerasi } & K0 & $2,50^{\mathrm{a}}$ \\
Melemak & K2 & $2,20^{\mathrm{a}}$ \\
& K3 & $1,40^{\mathrm{b}}$ \\
& K4 & $0,70^{\mathrm{bc}}$ \\
& K5 & $1,35^{\mathrm{b}}$ \\
\hline & $\mathrm{K} 0$ & $2,85^{\mathrm{a}}$ \\
& $\mathrm{K} 1$ & $2,55^{\mathrm{a}}$ \\
Nekrosis & K2 & $2,15^{\mathrm{b}}$ \\
& K3 & $1,90^{\mathrm{c}}$ \\
& $\mathrm{K} 4$ & $1,35^{\mathrm{d}}$ \\
& $\mathrm{K} 5$ & $2,60^{\mathrm{a}}$ \\
\hline
\end{tabular}

Ket: Nilai dengan huruf yang tidak sama menunjukkan berbeda nyata $(\mathrm{P}<0,05)$ sebaliknya nilai dengan huruf ada sama menunjukkan tidak berbeda nyata $(\mathrm{P}<0,05)$.

Degenerasi melemak pada kelompok ini mulai tidak ditemukan. Hasil tersebut membuktikan ekstrak daun kelor dengan dosis $400 \mathrm{mg} / \mathrm{KgBB}$ mampu memperbaiki lesi degenerasi melemak dan nekrosis pada diabetes melitus. Daun Moringa oleifera sendiri mengandung beragam polifenol dan flavonoid yang mampu bekerja sebagai insulin sekretagog atau insulinmimetik, yang akan meminimalisir komplikasi diabetes (Alethea et al., 2015). Selain itu daun kelor juga mengandung antioksidan yang dapat melawan kerusakan yang disebabkan oleh radikal bebas (Kurniasih, 2013). Radikal bebad normal biasanya dihasilkan oleh tubuh sebagai hasil sias-sisa metabolisme sel (Suastika, 2011).

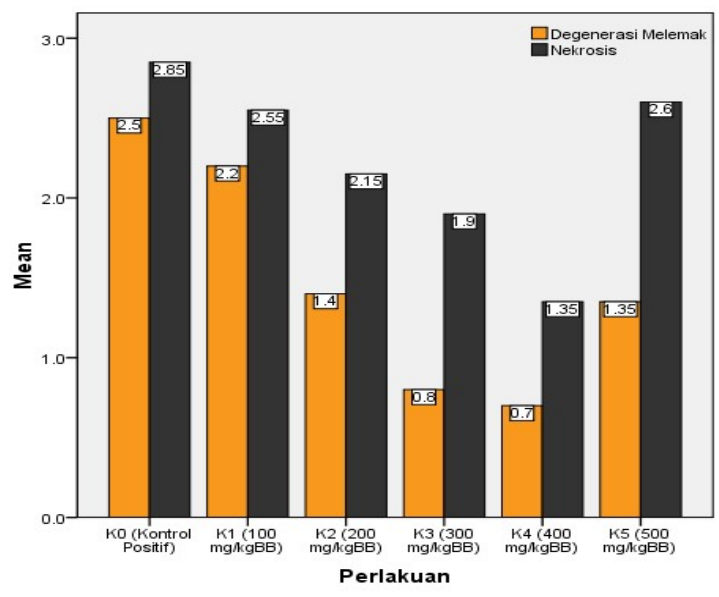

Gambar 2 Perubahan Histopatologi Hati Tikus Putih Dari Masing-Masing Perlakuan.

Gambaran histopatologi kelompok perlakuan K5 kembali menunjukkan kerusakan sel hati berupa degenerasi melemak dan nekrosis dengan tingkat kerusakannya menyerupai pada perlakuan K2 dan K0. Berdasarkan modus rata-rata degenerasi melemak bersifat multi fokal sedangkan nekrosis bersifat difusa. Nekrosis berupa piknosis dan beberapa inti sel yang hilang terlihat di lima lapang pandang serta sinusoid yang merenggang. Tapi di beberapa bagian, sel hati masih terlihat tidak mengalami kerusakan yang parah. Ini menandakan bahwa ekstrak daun kelor pada dosis $500 \mathrm{mg} / \mathrm{KgBB}$ bersifat bersifat prooksida yang menyebabkan lebih banyak lesi berupa nekrosis yang hampir sama jumlah dengan kelompok perlakuan K0 dan degenerasi melemak yang hampir seperti pada kelompok perlakuan K2.

Kerusakan struktur hati pada kelompok K5 disebabkan karena kandungan antioksidan yang berlebih pada pemberian dosis ekstrak etanol daun kelor 
yang menyebabkannya menjadi prooksida. Antioksidan umumnya menetralisir radikal bebas dan mencegah kerusakan yang ditimbulkan oleh radikal bebas terhadap sel normal, protein, dan lemak. Sebaliknya bila jumlah antioksidan tidak seimbang di dalam tubuh, akan menimbulkan kerusakan pada struktur organ, khususnya pada hati (Halliwell dan Gutteridge, 2007).

\section{SIMPULAN DAN SARAN}

\section{Simpulan}

Ekstrak etanol daun kelor (Moringa oleifera) dosis $400 \mathrm{mg} / \mathrm{KgBB}$ dapat memperbaiki kerusakan hati tikus putih yang mengalami diabetes melitus eksperimental berupa penurunan jumlah degenerasi melemak dan nekrosis.

\section{Saran}

Perlu dilakukan penelitian lebih lanjut mengenai penggunaan ekstrak daun kelor (Moringa oleifera) dengan dosis yang dianjurkan dan aman untuk memperbaiki kerusakan hati dalam jangka waktu yang lebih lama, serta pengaruh pemberian obat antara gabungan obat herbal dengan obat sintetik untuk penderita diabetes melitus.

\section{UCAPAN TERIMAKASIH}

Penulis mengucapkan terimakasih kepada Unit Layanan Laboratorium Fakultas Teknologi Pertanian Universitas Udayana, Laboratorium Patologi FKH Unud, dan Laboratorium Histologi FKH Unud, serta semua pihak yang telah mendukung dan membantu penelitian ini.

\section{DAFTAR PUSTAKA}

Adji D. 2008. Hubungan Konsentrasi Malondialdehida, Glukosa, dan Total Kolesterol Pada Tikus Putih yang Diinjeksi dengan Streptozotocin. $J$. Sain. Vet. 26(2): 73-77.

Aini Q, Sabri M, Samingan. 2015. Pemberian Ekstrak Daun Kelor (Moringa oleifera) Terhadap Kadar Glukosa Darah Pada Tikus Jantan (Rattus wistar) yang Diinduksi Aloksan. J. Edu. Bio. Trop. 3(1): 37-41.
Alethea T, Ramadhian MR. 2015. Efek Antidiabetik pada Daun Kelor. Majority. 4(9): 118-122.

Berata IK., Winaya IBO, Adi AAAM, Adnyana IBW, Kardena IM. 2014. Patologi Veteriner Umum. Edisi Kedua. Swasta Nulus.

Corwin EJ. 2001. Buku Saku Histofisiologi. Alih Bahasa dr BrahmU. Pendit, Sp.K. Penerbit Buku Kedokteran, ECG. Jakarta.

Cnop M, Weslh N, Jonas JC, Jorns A, Lenze S, Eizirik DC. 2005. Mechanisms of pancreatic $\beta$-cell in type 1 and 2 diabetes. Many differences, few similarities. Diabetes. 54(2): 97-107.

Dalimartha S. 2001. Ramuan Tradisional Untuk Pengobatan Hepatitis. Penebar Swadaya. Jakarta.

Dima LLRH, Fatimawali, Widya AL. 2016. Uji Aktivitas Antibakteri Ekstrak Daun Kelor (Moringa oleifera L.) Terhadap Bakteri Esceherichia coli dan Staphylococcus aureus. Pharmacon, J. Ilmiah Farmasi. 5(2): 282-289.

Edoga CO, Njoku OO, Amadi, EN, Okeke JJ. 2013.Blood Sugar Lowering Efect of Moringa oleifera Lam in Albino Rats. Int. J. Sci. Tech. 3(1).

Halliwell B, Gutteridge JMC. 2007. Free Radical in Biology and Medicine. Fourth edition, Oxford University Press, New York. Pp: 19-633.

International Diabetes Federation. 2014. Annual Report 2014.

Jaiswal D, Rai PK, Kumar A, Metha S, Watal G. 2009. Effect of Moringa oleifera Lam. leaves aqueous extract therapy on hyperglycemic rats. $J$. Ethnopharmacol. 123: 392-396.

Kiernan JA. 2001. Histological and Histochemical Methods. $3^{\text {rd }}$ Ed. Toronto Arnold Pub. Pp: 330-335.

Kurniasih. 2013. Khasiat dan Manfaat Daun Kelor Untuk Penyembuhan Berbagai Penyakit. Pustaka Baru Press: Yogjakarta.

Kurniawan IWAY, Wiratmini NI, Sudatri NW. 2014. Histologi Hati Mencit (Mus musculus L.) yang Diberi Ekstrak Daun 
Lamtoro (Leucaena leucocephal). $J$. Simbiosis. 2(2): 226-235.

Mardiastuti E. 2002. Gambaran Histopatologi Organ Hati dan Ginjal Tikus Diabetes Mellitus yang Diberi Infus Batang Brotowali (Tinospora tuberculata L.) Sebagai Bahan Antidiabetik. Skripsi, Institut Pertanian Bogor.

Nugroho AE. 2006. Hewan Percobaan Diabetes Melitus: Patologi dan Mekanisme Aksi Diabetogenik. Biodiversitas. 7(4): 378-382.

Putri WES. 2016. Pengaruh Penambahan Ekstrak Daun Kelor Terhadap Kualitas Sabun Transparan. e-J. UNESA. 5(1): 96-104.

Sampurna IP, Nindhia TS. 2008. Analisis Data dengan SPSS: Dalam Rancangan Percobaan. Udayana University Press, Denpasar.

Stumvoll M, Goldstein BJ, Van HTW. 2005. Type 2 Diabetes: Principles of Pathogenesis and Therapy. Lancet. 365: 1333-1346.

Suarsana IN, Priosoeryanto BP, Wresdiyati T, Bintang M. 2010. Sintesis Glikogen Hati dan Otot pada Tikus Diabetes yang Diberi Ekstrak Tempe. J. Vet. 11(3): 190-195.
Suartha IN, Swantara IM, Rita WS. 2016. Ekstrak Etanol dan Fraksi Heksan Buah Pare (Momordica charantia) Sebagai Penurun Kadar Glukosa Darah Tikus Diabetes. J. Vet. 17(1): 30-36.

Suastika P. 2011. Efek Pemberian Buah Merah (Pandanus conoideus) Terhadap Perubahan Histopatologik Ginjal dan Hati Mencit Pasca Pemberian Paracetamol. Bul. Vet. Udayana. 3(1): 39-44.

Swarayana IMI, Sudira IW, Berata IK. 2012. Perubahan Histopatologi Hati Mencit (Mus musculus) yang Diberikan Ekstrak Daun Ashitaba (Angelica keiskei). Bul. Vet. Udayana. 4(2): 119125.

Syukur R, Alam G, Mufidah, Rahim A, Taeyeb R. 2011. Aktivitas Antiradikal Bebas Beberapa Ekstrak Tanaman Familia Fabaceae. JST. Kesehatan. 1(1) 1411-1674.

Yulinta NMR, Gelgel KTP, Kardena IM. 2013. Efek Toksisitas Ekstrak Daun Sirih Merah Terhadap Gambaran Mikroskopis Ginjal Tikus Putih Diabetik yang Diinduksi Aloksan. Bul. Vet. Udayana. 5(2): 114-121. 